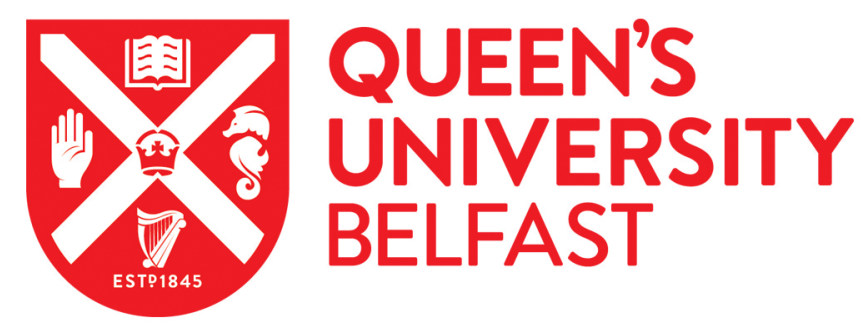

\title{
Review of Childhood and Nineteenth-Century American Theatre: The Work of the Marsh Troupe of Juvenile Actors
}

Lamb, E. (2017). Review of Childhood and Nineteenth-Century American Theatre: The Work of the Marsh Troupe of Juvenile Actors. The Journal of the History of Childhood and Youth, 10(1), 139-141.

https://doi.org/10.1353/hcy.2017.0014

\section{Published in:}

The Journal of the History of Childhood and Youth

Document Version:

Publisher's PDF, also known as Version of record

Queen's University Belfast - Research Portal:

Link to publication record in Queen's University Belfast Research Portal

Publisher rights

Copyright ( 2017 The Johns Hopkins University Press. This article first appeared in The Journal of the History of Childhood and Youth, Volume 10, Issue 1, Winter 2017, pages 139-141.

\section{General rights}

Copyright for the publications made accessible via the Queen's University Belfast Research Portal is retained by the author(s) and / or other copyright owners and it is a condition of accessing these publications that users recognise and abide by the legal requirements associated with these rights.

Take down policy

The Research Portal is Queen's institutional repository that provides access to Queen's research output. Every effort has been made to ensure that content in the Research Portal does not infringe any person's rights, or applicable UK laws. If you discover content in the Research Portal that you believe breaches copyright or violates any law, please contact openaccess@qub.ac.uk. 


\section{PROJECT MUSE}

Childhood and Nineteenth-Century American Theatre: The Work of the Marsh Troupe of Juvenile Actors by Shauna Vey (review)

Edel Lamb

The Journal of the History of Childhood and Youth, Volume 10, Number 1, Winter 2017, pp. 139-141 (Review)

Published by Johns Hopkins University Press

DOI: https://doi.org/10.1353/hcy.2017.0014

$\Rightarrow$ For additional information about this article https://muse.jhu.edu/article/646759 
Ponzio also assumes no prior knowledge of either regime's history, making this an excellent choice for both undergraduate and graduate reading lists.

Joan L. Clinefelter

University of Northern Colorado

\section{Childhood and Nineteenth-Century American Theatre: The Work of the Marsh Troupe of Juvenile Actors.}

By Shauna Vey.

Carbondale: Southern Illinois University Press, 2015. xv + 217 pp. Paper $\$ 40.00$.

Shauna Vey's Childhood and Nineteenth-Century American Theatre is a fascinating history of the Marsh Troupe of Juvenile Comedians. This company of approximately thirty children toured from 1855 until 1863 performing popular plays for adult audiences. Vey impressively pieces together their activities to illuminate the economic, staging, and touring practices common to many troupes and the experiences of children in mid-nineteenth-century America. She participates in the recent scholarly trend to uncover the experiences of children through empirical and archival research to interrogate ahistorical assumptions. Vey's book is a welcome addition to this field. She does recover some of the "lost voices" and experiences of children. Moreover, by interrogating the experiences of these professional children at "the moment just before American childhood would be utterly transformed," she productively engages with debates around sentimental and economic understandings of childhood and questions of childhood autonomy (7). Acknowledging the paradoxical understandings of childhood at a moment in which the notion of the protected and sentimentalized child was gaining force and attitudes towards child labor were changing, Vey focuses on the professionalism of this troupe and its young performers to interrogate what it meant to be a child at this significant historical juncture.

Vey's study is a micro-history, and she persuasively asserts its value by claiming that the history of this little-known company is the "perfect vehicle for exploring the world of nineteenth-century actors and examining the societal construction of childhood, just as both were changing" (143). While she 


\section{0}

draws occasional connections with other instances of children's performance throughout history, the study is strongest when she focuses on the connections, and differences, between this juvenile troupe and wider theatrical practices and child performers in the period. The book's careful structure facilitates the creation of an interesting narrative around the company that simultaneously engages with a series of larger thematic concerns pertinent to childhood studies. Following an introduction that ably sets out the case for the importance of this subject, six chapters explore the wider implications of child performance via a focus on different periods in the company's brief history and its major personalities. Chapter 1 recounts the familial origins of the company by focusing on its founder, Robert Marsh, offering a vivid insight into the repertoires and practices of this novel company. Chapter 2 examines some of the difficulties faced by the company in the late 1850s and reads contractual documents and legal wrangling between Marsh and the parents of two actors, Louise Arnot and Alfred Stewart, to raise questions about the personal or collective agency of these child actors. It provides an exceptional view into the economic position of the child within cultures of labor and apprenticeship. Chapter 3 concentrates on Mary Marsh, daughter of the founder, who died in a horrific onstage accident. Analyzing her roles and contemporary perceptions of her as innocent victim, Vey proposes that her short acting career propagated the sentimentalization of the child. This chapter usefully extends Vey's consideration of the curious paradoxes of the multiple versions of childhood in the mid-nineteenth century. Chapter 4 moves on to consider how the company overcame the difficulties posed by Mary's death, the approaching civil war, and the fact that the children were aging. Vey stresses Robert Marsh's role as a theatrical innovator as he takes advantage of opportunities to tour to California, Australia, and New Zealand. This chapter depicts the company as a professional and economic entity prepared to adapt to survive, even though, in spite of Marsh's new strategies, the company would ultimately disband in 1863 when many of the key actors had grown up and moved on. The final two chapters return to focus on important actors: Louise Arnot, the company's "leading man," in chapter 5 and Georgie Marsh, the comic, in chapter 6. By charting the lives of these players, Vey powerfully conveys the extent to which their experiences as child performers equipped them with the skills to negotiate their careers in and beyond the world of theater. The analyses of their roles as child actors illuminate the extent to which the acting styles, typecasting, and cross-dressing practices of the Marsh troupe complicated traditional views of childhood. The detailed examination of Arnot's life in theater is particularly interesting in the challenges it poses to paradigms of fragile Victorian girlhood. 
Ultimately, Vey persuades that this minor company is worthy of critical attention, dispelling any diminutive assumptions about the professional significance of a children's troupe. This company, Vey insists, made an important contribution to nineteenth-century American theater by training a substantial number of young actors and establishing a model for the juvenile companies of the next generation. Most significantly, she provides a fresh perspective on the experiences of touring professional actors, child performers, and antebellum children through her close focus on this previously overlooked troupe of children.

Edel Lamb

Queen's University Belfast

\section{Childhood and Colonial Modernity in Egypt.}

By Heidi Morrison.

New York: Palgrave Macmillan, 2015. xii + 176 pp. Cloth \$90, e-book \$69.99.

hildhood studies, as embodied in three decades of the New Social Studies of Childhood (NSSC), has finally arrived to colonial Egypt. Heidi Morrison's well-researched and accessible volume, Childhood and Colonial Modernity in Egypt, is based on the premise that childhood is a legitimate and vital category of historical analysis and that children constitute "active historical agents" (8). Morrison belabors the point that attention to children's agency should not be equated with a linear approach to modernity, nor with supporting the notion that Western middle-class childhood constitutes the model for global childhood. Rather, this work situates children's lives and agency within the local frame of Egypt and in so doing contributes to a growing body of work on "nonwestern childhoods."

The book covers a much-researched period of Egyptian history, namely the late nineteenth to early twentieth century. Although it walks on well-trodden ground, this work offers a valuable contribution to the literature since it interprets historical change from the unique lens of Egyptian childhood. This style of revisionist history, which takes children as actors in nation-building, arrives four decades after feminist historians began incorporating the lives and struggles of women into the historical record. Children feature in the literature on women and the family to be sure, but they appear mainly as appendages to their mothers rather than active agents of development and change in their 